\title{
Effect of level of egg content on the quality of pudding using reconstituted milk
}

\section{MA Khatun*, MN Islam and MA Islam}

${ }^{1}$ Department of Dairy Science, Faculty of Animal Husbandry, Bangladesh Agricultural University, Mymensingh 2202, Bangladesh

\begin{abstract}
The study was conducted to analyze the physical and chemical parameters of manufactured pudding and to recommend acceptable level of eggs for the manufacture of pudding. Reconstituted milk was prepared by using the instructions given on the packet of whole milk powder. The prepared reconstituted milk was divided into three parts and three different types of puddings were prepared by using 2 eggs, 3 eggs and 4 eggs with reconstituted milk. Amount of milk, sugar and corn flour level was same in all three types. The puddings were designated as A (2 eggs), B (3 eggs) and C (4 eggs) types. Prepared pudding samples were subjected to physical and chemical analysis to monitor their quality. Physical properties (smell, color, consistency and texture) showed pudding that contained 3 eggs obtained the best score $(89.13 \pm 3.77)$ from the judges. From chemical analysis, it was observed that 4 eggs containing pudding showed the highest nutritive value as compared to control and other group but organoleptic score was highest for 3 eggs containing pudding.
\end{abstract}

Key words: pudding, reconstituted milk, full cream milk powder, eggs, corn flour

Bangladesh Animal Husbandry Association. All rights reserved.

Bang. J. Anim. Sci. 2018. 47 (2):92-97

\section{Introduction}

The dairy industry of Bangladesh is progressing over the years and today there are a wide variety of milk and dairy products readily available in the market for the consumers. Milk and milk products are known as functional foods in view of the fact that a number of bioactive components have been discovered in milk (Bhat and Bhat, 2011). There are lots of products (like yogurt, cheese, sweetmeats, custard, pudding etc.) that can be made from milk. Out of the above dairy products pudding is one of the most popular items for the rural and urban people. People can easily prepare it from the available ingredients that involve less cost. Pudding is very tasty and easily digestible food item. It is a soft dessert, with a base of milk or cream thickened by flour, cornstarch, or a cereal product, that has been boiled, steamed, or baked (American Heritage $\AA$ Dictionary of the English Language, 2016). Pudding of different varieties has been prepared by different scientists throughout the world depending on their acceptability by the consumers. Marina and Azizah (2014) prepared custard pudding by using instant coconut milk (ICM), fresh coconut milk (FCM), fresh milk (FM) and evaporated milk (EM).
Marina and Azizah (2014) found that pudding containing fresh coconut milk obtained high organoleptic score from the judges. In another experiment Rajadhyax et al. (2000) found that the tender copra and water of tender coconut could be successfully utilized for preparation of milk pudding using gelatin as the jelling agent. Sun Yuan Xia et al. (2007) reported that considerable amount of antioxidant substances could be formed through Millard reaction during preparation of pudding. Pudding is widely accepted by people in our country. If it is prepared maintaining proper hygienic conditions and compositional standards, this product could be an excellent supplementary food item in our diet. So, as a rich source of fat and protein, pudding may play a very important role to alleviate the protein-caloric malnutrition problem in our country. We have short supply of whole milk and for this reason it becomes difficult to prepare protein as and when necessary. Reconstituted milk could be an alternate of whole milk for this purpose. No research work has been done in our country for making pudding from reconstituted milk. For this reason the present experiment was conducted with an aim to prepare pudding from reconstituted milk by adding different level of eggs.

*Corresponding author: arifads180@gmail.com 


\section{Materials and Methods}

The experiment was conducted at the Laboratory of Dairy Technology, Dairy Chemistry, and Dairy Microbiology of the Department of Dairy Science, Bangladesh Agricultural University (BAU), Mymensingh2202, Bangladesh. Powdered milk (Aarong Brand), corn flour, sugar and chicken eggs were purchased from different stores of Mymensingh town and BAU Poultry Farm,Mymensingh-2202, Bangladesh. At first $1 \mathrm{~L}$ reconstituted milk was prepared by mixing $125 \mathrm{~g}$ of whole milk powder and $875 \mathrm{ml}$ of fresh luke warm water. Three different types of pudding were prepared from reconstituted milk (RM). For each type $500 \mathrm{ml}$ of RM was taken, then heated to boiling temperature to reduce approximately $50 \%$ of the volume. During heating, milk was slowly stirred with the help of a spoon to avoid burning. In one part, 2 eggs $(107.90 \mathrm{~g}), 10 \mathrm{~g}$ (2\%) corn flour, $75 \mathrm{~g}(15 \%)$ sugar were mixed properly by blending with $500 \mathrm{ml}$ reconstituted milk (Pudding A).

In another part, 3 eggs (155.65 g), $10 \mathrm{~g} \mathrm{(2 \% )}$ corn flour, $75 \mathrm{~g}(15 \%)$ sugar were added (Pudding B) and in third part, 4 eggs (202.82 g), $10 \mathrm{~g}(2 \%)$ corn flour, $75 \mathrm{~g}(15 \%)$ sugar (Pudding C) were mixed properly with $500 \mathrm{ml}$ reconstituted milk. The mix was then taken in the mould and covered properly. The mould was placed in the pan half-full of boiled water and kept for 1-1.5 hrs until the mix coagulated. After optimum cooling at room temperature, the mould was placed in the refrigerator $\left(4^{\circ} \mathrm{C}\right)$ for about 2 hrs for cooling and the pudding was ready to serve.

After preparation the quality of pudding was judged by some physical and chemical tests which were:

i. Smell and taste (50 marks)

ii. Body and consistency (20 marks)

iii. Color and Appearance (30 marks)

On the other hand, samples were also chemically analyzed for measuring the following parameters

\section{Fat content $(\mathbf{g} / \mathbf{k g})$}

Two gram sample was taken in a crucible and poured into the thimble. The extraction required a water bath at $45^{\circ} \mathrm{C}$ for 2 hrs. It took 30 minutes for oven dried. The difference between the weight after and before extraction gave the amount of ether extract.

\section{Protein content $(\mathbf{g} / \mathbf{k g})$}

Protein was determined by Kjeldhal procedure.
The determination of crude protein (CP) actually involves the determination of nitrogen content of the sample which was then multiplied by the factor 6.38 .

\section{Carbohydrate content $(\mathrm{g} / \mathrm{kg})$}

Carbohydrate content of samples was not determined directly. It was calculated by total sum of moisture, fat, protein, ash percentage subtracting from 100 .

\section{Ash content $(\mathbf{g} / \mathbf{k g})$}

Five gram sample was taken into a crucible. The sample was ignited in muffle furnace at $600^{\circ} \mathrm{C}$ for $5 \mathrm{hrs}$. After removing and cooling in the desiccators, the ash was calculated.

\section{Total Solids $(\mathbf{g} / \mathbf{k g})$}

Five grams of sample in a crucible was heated at $105^{\circ} \mathrm{C}$ for $24 \mathrm{hrs}$. The difference of the weight was used to calculate the TS content in relation to initial weight.

\section{Moisture (g/kg)}

Moisture content of different types of samples was determined by Oven Drying method as per (AOAC, 2012).

\section{Acidity (\%)}

Acidity content of different types of samples was determined as per AOAC, 2012.

\section{$\mathbf{p}^{\mathbf{H}}$ value}

$p^{H}$ was measured with $\mathrm{H} 12211 / \mathrm{ORP} \mathrm{p}^{\mathrm{H}}$ Meter (HANNA Instruments USA,1978).

\section{Data analysis}

In this experiment, experimental materials were completely homogenous. So, the analysis of variance (ANOVA) test was done by Completely Randomized Design (CRD). In case of significant difference, Duncan's Multiple Range Test (DMRT) was carried out to find out the significant difference among different treatment means. Statistical program SAS (Statistical analysis System, 2009) was used for data analysis.

\section{Results}

\section{Quality of pudding}

The physical and chemical properties of pudding prepared in the laboratory were evaluated to monitor the quality of pudding. Results obtained on different parameters are summarized and presented in Table 1 and 2. 


\section{Physical evaluation}

\subsection{Smell and Taste score}

Average smell and taste scores of A, B and C pudding samples were $41.50 \pm 0.82,45.63 \pm .53$ and $44.38 \pm 1.51$ respectively (Table 1 ); $(p<0.05)$.

\subsection{Body and consistency score}

Average body and consistency scores A, B and $C$ pudding samples were $14.75 \pm 0.31$, $16.88 \pm 0.3$ and $16.38 \pm 0.42$ respectively (Table $1)$; $(p<0.01)$.

\subsection{Color and appearance score}

Average color and appearance scores of A, B and $C$ pudding samples were $23.88 \pm 0.72$, $26.63 \pm 0.56$ and $26.38 \pm .0 .73$ respectively (Table 1); $(p<0.05)$.

\subsection{Overall score}

The average overall score of pudding samples $A, B$ and $C$ on the basis of smell and taste, body and consistency, color and appearance were $80.13 \pm 1.14, \quad 89.13 \pm 1.16$ and $87.13 \pm 2.37$ respectively (Table1); $(p<0.01)$.

\section{Chemical Parameters}

\subsection{Fat content}

The average fat content of $A, B$ and $C$ pudding was $60.6 \pm 0.2,62.7 \pm 0.4$ and $64.0 \pm 0.6 \mathrm{~g} / \mathrm{kg}$, respectively (Table 2$)$; $(p<0.05)$.

\subsection{Protein content}

The average protein content of $A, B$ and $C$ pudding was $63.6 \pm 0.2,68.0 \pm 1.1$ and $71.3 \pm 0.1$ $\mathrm{g} / \mathrm{kg}$ respectively (Table 2$) ;(p<0.001)$.

\subsection{Carbohydrate content}

The average carbohydrate content of A, B and C pudding was $260.5 \pm 0.6,264.1 \pm 1.1$ and $277.0 \pm 1.1 \mathrm{~g} / \mathrm{kg}$ respectively (Table 2); $(p<0.001)$.

\subsection{Ash content}

The average ash content of 2, 3 and 4 eggs containing pudding was $51.5 \pm 3.7,55.6 \pm 1.4$ and $57.2 \pm 0.2 \mathrm{~g} / \mathrm{kg}$ respectively (Table 2 ); $(p>0.05)$.

\subsection{Total solids (TS) content}

The average total solids content of A, B and C pudding was $436.2 \pm 3.8,450.4 \pm 0.9$ and $469.5 \pm 0.5 \mathrm{~g} / \mathrm{kg}$ respectively (Table 2); $(p<0.001)$.

\subsection{Moisture content}

The average moisture content of $A, B$ and $C$ pudding was $563.8 \pm 3.8,549.9 \pm 0.7$ and $530.5 \pm 0.5 \mathrm{~g} / \mathrm{kg}$ respectively (Table 2); $(p<0.001)$.

\subsection{Acidity content}

The average acidity content of $\mathrm{A}, \mathrm{B}$ and $\mathrm{C}$ pudding was $0.10 \pm 0.006,0.09 \pm 0.006$ and $0.09 \pm 0.006$ respectively (Table 2$) ;(p>0.05)$.

\section{$2.8 \mathrm{p}^{\mathrm{H}}$}

The average $\mathrm{p}^{\mathrm{H}}$ content of $\mathrm{A}, \mathrm{B}$ and $\mathrm{C}$ pudding was $6.50 \pm 0.06,6.77 \pm 0.16$ and $6.94 \pm 0.05$ respectively (Table 2 ).

Table 1: Average score of various physical characteristics of different types of pudding containing reconstituted milk and different levels of egg

\begin{tabular}{lccccc}
\hline Parameter & \multicolumn{3}{c}{ Types of pudding } & p-Value & $\begin{array}{c}\text { Level of } \\
\text { significance }\end{array}$ \\
\cline { 2 - 5 } & $\mathrm{A}$ & $\mathrm{B}$ & $\mathrm{C}$ & & $*$ \\
\hline Smell and Taste & $41.50^{\mathrm{b}} \pm 0.8$ & $45.63^{\mathrm{a}} \pm 0.5$ & $44.38^{\mathrm{ab}} \pm 1.6$ & 0.03 & $* *$ \\
Body and Consistency & $14.75^{\mathrm{b}} \pm 0.3$ & $16.88^{\mathrm{a}} \pm 0.3$ & $16.38^{\mathrm{a}} \pm 0.4$ & 0.08 & $* * *$ \\
Color and appearance & $23.88^{\mathrm{b}} \pm 0.7$ & $26.63^{\mathrm{a}} \pm 0.6$ & $26.38^{\mathrm{a}} \pm 0.7$ & 0.02 & $*$ \\
Overall Score & $80.13^{\mathrm{b}} \pm 1.1$ & $89.13^{\mathrm{a}} \pm 1.2$ & $87.13^{\mathrm{a}} \pm 2.4$ & 0.025 & $* *$ \\
\hline
\end{tabular}

$A=2$ Eggs, $B=3$ Eggs, $C=4$ Eggs. Means with difference superscript in the same row differ significantly $*=$ Significant at $5 \%, * *=$ Significant at $1 \%, * * *=$ Significant at $0.1 \%$. 
Sultana (2007) reported that flavor and egg level influences the smell and taste score of pudding. Marina and Azizah (2014) mentioned that addition of fresh coconut milk with pudding enhanced the smell and taste score of custard pudding.

\section{Discussion}

\section{Physical evaluation}

\subsection{Smell and Taste score}

Smell and taste score of B type pudding was significantly $(p<0.05)$ higher than A type pudding but significant difference does not seen within the smell and taste score of the $B$ and $C$ type sample. This result indicates that panelists choose the pudding prepared by using 3 eggs ( $B$ type). When number of eggs increases then flavor dominates over the flavor of other ingredients of pudding. For this reason pudding containing 4 eggs ( $C$ type) obtained lower score than the pudding containing 3 eggs ( $B$ type).

\subsection{Body and consistency score}

Body and consistency score of B (3 eggs) type pudding was significantly $(p<0.001)$ higher than A type pudding but there was no significant difference between type $B$ and type $C$. This result indicates that panelists choose the pudding prepared by using 3 eggs ( $B$ type). Rajadhyax et al. (2000) reported that body and consistency score of pudding can be improved by adding small amount of gelatin.

\subsection{Color and appearance score}

In case of color and appearance scores of pudding samples, there was no significant $(p<0.05)$ difference between B (3 eggs) and C type (4 eggs) samples but there was significant difference between type A ( 2 eggs) and B (3 eggs). This result indicates that eggs can enhance the color and appearance score of pudding.

\subsection{Overall score}

The test showed that there was no significant $(p<0.05)$ difference between B and C type samples but there was significant difference between type $A$ and $B$. The highest value was observed in type $B$ and the lowest value was found in type A. Result of overall score indicates three eggs per $500 \mathrm{ml}$ reconstituted milk is better for pudding preparation.

\section{Chemical Parameters}

\subsection{Fat content}

Fat content score of $C$ type pudding was significantly $(p<0.01)$ higher than A type pudding but significant difference does not exist within the score of the $B$ and $C$ type sample. Soledad et al.(1995) found that the pudding type desert powder contained $52 \mathrm{~g}$ fat which was much higher than the custard pudding that contained $2.8 \mathrm{~g}$ fat (Marina and Azizah, 2014). In our experiment, the highest value was showed by the $C$ type $(64 \mathrm{~g} / \mathrm{kg})$ and lowest value was observed by the A type $(60.6 \mathrm{~g} / \mathrm{kg})$. Higher level of fat in $C$ type pudding might be due to addition of more eggs.

Table 2: Average chemical composition of different types of pudding samples prepared with reconstituted milk and different egg levels

\begin{tabular}{|c|c|c|c|c|c|}
\hline \multirow[t]{2}{*}{ Parameter } & \multicolumn{3}{|c|}{ Types of pudding } & \multirow[t]{2}{*}{ p-Value } & \multirow{2}{*}{$\begin{array}{l}\text { Level of } \\
\text { significance }\end{array}$} \\
\hline & $\mathbf{A}$ & B & C & & \\
\hline Fat $(\mathrm{g} / \mathrm{kg})$ & $60.6^{b} \pm 0.2$ & $62.7^{\mathrm{a}} \pm 0.4$ & $64.0^{\mathrm{a}} \pm 0.6$ & 0.004 & $* * *$ \\
\hline Protein $(\mathrm{g} / \mathrm{kg})$ & $63.6^{c} \pm 0.2$ & $68.0^{b} \pm 1.1$ & $71.3^{\mathrm{a}} \pm 0.1$ & 0.0006 & $* * *$ \\
\hline Carbohydrate $(\mathrm{g} / \mathrm{kg})$ & $260.5^{\mathrm{c}} \pm 0.6$ & $264.1^{b} \pm 1.1$ & $277.0^{\mathrm{a}} \pm 1.1$ & 0.0001 & $* * *$ \\
\hline Ash $(\mathrm{g} / \mathrm{kg})$ & $51.5 \pm 3.7$ & $55.6 \pm 1.4$ & $57.2 \pm 0.2$ & 0.26 & NS \\
\hline Total solids $(\mathrm{g} / \mathrm{kg})$ & $436.2^{c} \pm 3.8$ & $450.4^{b} \pm 0.9$ & $469.5^{\mathrm{a}} \pm 0.5$ & 0.0001 & $* * *$ \\
\hline Moisture (g/kg) & $563.8^{\mathrm{a}} \pm 3.8$ & $549.9^{b} \pm 0.7$ & $530.5^{c} \pm 0.5$ & 0.0001 & $* * *$ \\
\hline Acidity (\%) & $0.01 \pm .006$ & $0.09 \pm 0.006$ & $0.09 \pm 0.006$ & 0.42 & NS \\
\hline$p^{H}$ & $6.50^{b} \pm 0.06$ & $6.77^{\mathrm{ab}} \pm 0.16$ & $6.94^{\mathrm{a}} \pm 0.05$ & 0.055 & NS \\
\hline
\end{tabular}

$A=2$ Eggs, $B=3$ Eggs, $C=4$ Eggs; Means with difference superscript in the same row differ significantly, $* * *=$ Significant at $0.1 \%, N S=$ Non-significant. 
Khatun (2009) prepared pudding from whole milk and whole milk powder with constant level of egg and found fat $(65.64 \pm 3.26 \mathrm{~g} / \mathrm{kg})$ and $(56.25 \pm 0.45 \mathrm{~g} / \mathrm{kg})$ fat which was significantly differed $(p<0.01)$ from each other. Other findings were showed by Sultana (2007) who prepared pudding from different level of flour ( $2 \%, 4 \%$ and $6 \%$ )with egg ( 3 and 4 numbers) showed that the fat $(60.59 \pm 0.95,60.22 \pm$ 0.94 and $59.97 \pm 0.85 \mathrm{~g} / \mathrm{kg}$ ) which were not significantly differed. In this experiment, our result followed the same trend and this result also agreed with Sultana (2007) but differed from Khatun (2009).

\subsection{Protein content}

Protein content score of $C$ type pudding was significantly $(p<0.001)$ higher than A and $B$ type pudding. From an experiment Marina and Azizah, (2014) observed that the custard pudding that was prepared by Fresh Milk (FM) contained the highest protein $29.8 \mathrm{~g}$, whereas Demarg et al. (1999) showed that the milk pudding contained the higher amount of protein $(50 \mathrm{~g})$. On the other hand, Soledad et al. (1995) found that the pudding type desert powder contained $11 \mathrm{~g}$ protein. But the recent study showed that the $C$ type pudding contained highest amount of protein $(71.3 \mathrm{~g} / \mathrm{kg}$ ) and $A$ type pudding had the lowest result $(63.6 \mathrm{~g} / \mathrm{kg})$. That might be due to more egg content.

\subsection{Carbohydrate content}

The average carbohydrate content of different pudding samples are presented in Table 2 . Statistical analyses showed that there were significant differences $(p<0.01)$ among the carbohydrate contents of different pudding samples. Carbohydrate content score of $C$ type pudding was significantly $(p<0.01)$ higher than $A$ and $B$ type pudding.

Soledad et al.(1995) found that the pudding type desert powder contained $896 \mathrm{~g}$ carbohydrates whereas lower amount of carbohydrates was found in the current study. Khatun (2009) prepared pudding from whole milk and whole milk powder with constant level of egg and found that the pudding contained $(200.56 \pm 0.58 \mathrm{~g} / \mathrm{kg})$ and $(206.22 \pm 2.05 \mathrm{~g} / \mathrm{kg})$ carbohydrate, whereas Sultana (2007) reported that their prepared pudding obtained $(160.26 \pm 1.12,169.53 \pm 1.18$ and $178.67 \pm 1.27$ $\mathrm{g} / \mathrm{kg}$ ) carbohydrate.

\subsection{Total solids (TS) content}

Total solids (TS) content score of $C$ type pudding was significantly $(p<0.001)$ higher than $A$ and $B$ type pudding. The total solids content of egg is higher than milk so, it was increased in pudding when egg ratio was increased in manufacturing pudding. Rather et al. (2012) reported that the significant $(p<0.05)$ increase in total solids content $(275.7 \mathrm{~g} / \mathrm{kg})$ was due to decrease in moisture content by increasing the quantity of semolina level in the mix that was lower than the recent study.

\subsection{Moisture content}

Moisture content of $A$ type pudding was significantly $(p<0.001)$ higher than $B$ and $C$ type pudding. The type $A$ contained highest moisture and lowest in type $C$ due to less egg level. Rather et al. (2012) conducted work to standardize the processing parameters for the preparation of ready to mix semolina-milk dessert using skim and whole milk powders. Significantly lower $(p<0.05)$ moisture content $(724.3 \mathrm{~g} / \mathrm{kg}$ ) was found due to increase in TS by increasing the quantity of semolina level in the mixture. That was higher than the present study.

\subsection{Acidity content}

The acidity content of A, B and C types pudding were more or less similar. There were no significant differences $(p>0.05)$ among the pudding samples. This study indicated that the different level of eggs had no significant effect on the acidity percentage of pudding samples. Sarker (2008) reported the mean of acidity content was $0.071 \pm 0.00$ which was similar with the present study. But Khatun (2009) and Sultana (2007) reported the mean were $0.70 \pm 0.00$ and $0.074 \pm 0.00$, respectively which was contradicted with the present study.

\section{$2.7 p^{H}$}

The average value of $\mathrm{pH}$ of all three type protein was nearly similar and no significant difference was seen between them. Although there was no significant difference but it was observed that $\mathrm{pH}$ value increased little with addition of more eggs. Ohenhen et al. (2013) observed that $\mathrm{p}^{\mathrm{H}}$ of the plantain pudding decreased from 5.7 to 4.7 after boiling. Helland et al. (2004) also observed the growth and metabolism of probiotic strains in milk and water-based puddings containing both maize and rice flour, where milk-based pudding had significantly $(p<0.05)$ higher concentrations of $\mathrm{p}^{\mathrm{H}}$ levels.

\section{Conclusion}

Three eggs per $500 \mathrm{ml}$ of reconstituted milk is optimum for better organoleptic score. Chemical evaluation indicated that fat, protein, 
carbohydrate, total solids etc. were higher in 4 eggs containing pudding. Finally from this experiment, it may be concluded that reconstituted milk could be used for preparation of pudding.

\section{Acknowledgement}

The author is grateful to Department of Dairy Science of Bangladesh Agricultural University for providing necessary reagents and other essential supports for conducting the research.

\section{References}

American Heritage $\AA$ Dictionary of the English Language (2016). Fifth Edition.Copyright (C) by Houghton Mifflin Harcourt Publishing Company. Published by Houghton Mifflin Harcourt Publishing Company. USA.

Bhat ZF and $\mathrm{H}$ Bhat (2011). Milk and dairy products as functional foods: A Review. International Journal of Dairy Science 6:1-12.

Demrag K, Y Elmac and $T$ Altug (1999). Formulation and quality evaluation of reduced sugar and reduced calorie kazandibi. Journal of Food Quality 22(1):101-108.

Khatun M (2009). A comparative study on quality of pudding prepared by whole milk and whole milk powder. M.S Thesis. Department of Dairy Science, Bangladesh Agricultural University, Mymensingh.

Marina AM and S Azizah (2014). Use of coconut versus dairy milk products in Malaysian dishes: Comparison of nutritional composition and sensory evaluation. Journal of Food and Nutrition Research 2(4):204-208.
Ohenhen RE, IB Enweani, SI Ogiehor and $\mathrm{K}$ Uwabor (2013). Microorganisms associated with the preparation of plantain pudding in Western Nigeria. African Journal of Microbiology 1(2):37-39.

Rajadhyax P, VA Toro and SV Joshi (2000). Utilization of tender coconut for preparation of milk pudding. Indian Journal of Dairy Science 53(6):419-423.

Rather FA, MA Pal, SU Khan and H Jalal (2012). Preparation of ready to mix semolina milk pudding-Kashmiri fireen. International Journal of Food Nutrition and Safety 2(2):4654.

Sarker MNH (2008). Manufacture of buffalo milk pudding with different levels of egg. M.S. Thesis. Department of Dairy Science, Bangladesh Agricultural University, Mymensingh.

Soledad Vera M, Witting. E De.Penna, A Bunger, D Soto, L Cariaga, R Fuenzalida, E Cornejo, L Lopez and EW De Penna (1995). Development of nutritious products for elderly people: vitamin enriched pudding. Archivos Latinoamericanos de Nutrition 45(1):63-66.

Sultana S (2007). Milk pudding manufacture with different level of corn flour and egg. M.S. Thesis. Department of Dairy Science, Bangladesh Agricultural University, Mymensingh.

Sun Y, S Hayakawa, M Ogawa and $\mathrm{K}$ Izumori (2007). Antioxidant properties of custard pudding dessert containing rare hexose, D psicose. Food Control 18(3): 220-227.

FAO/WHO (1998). Vitamin and mineral requirements in human nutrition. Report of a joint expert consultation, Bangkok, Thailand. 